\title{
Education and Leadership in Indonesia: A Trilogy Concept in Islamic Perspective
}

\author{
Muthoifin ${ }^{1, *}$, Nuha $^{2}$, Sudarno Shobron ${ }^{1}$ \\ ${ }^{1}$ Department of Islamic Education, Faculty of Islamic Studies, Universitas Muhammadiyah Surakarta, Indonesia \\ ${ }^{2}$ Department of Arabic Language Education, Faculty of Islamic Studies, Institut Agama Islam Negeri Surakarta, Indonesia
}

Received March 12, 2020; Revised May 19, 2020; Accepted August 28, 2020

\section{Cite This Paper in the following Citation Styles}

(a): [1] Muthoifin, Nuha, Sudarno Shobron, "Education and Leadership in Indonesia: A Trilogy Concept in Islamic Perspective," Universal Journal of Educational Research, Vol. 8, No. 9, pp. 4282-4286, 2020. DOI: 10.13189/ujer.2020.080954.

(b): Muthoifin, Nuha, Sudarno Shobron (2020). Education and Leadership in Indonesia: A Trilogy Concept in Islamic Perspective. Universal Journal of Educational Research, 8(9), 4282-4286. DOI: 10.13189/ujer.2020.080954.

Copyright $(\mathcal{O} 2020$ by authors, all rights reserved. Authors agree that this article remains permanently open access under the terms of the Creative Commons Attribution License 4.0 International License

\begin{abstract}
This study aims to uncover the basis used to construct the leadership trilogy in Indonesia, and examine it from Islamic education perspective, using a qualitative model with literature study. Meanwhile, data is obtained through written relics, both in form of books, journals and proceedings relevant to the subject. Furthermore, a historical, biographical and normative approach is used, and the data analysis techniques used are content, comparative and inductive. Based on the discussions, there are three bases used to construct leadership theory, and it is often referred to as the trilogy concept, which are ing ngarso sung tulodo, ing madyo mangun karso, tut wuri handayani. The meaning of these theories is "in front should set an example", "in the middle should take initiative and be cooperative" and "at the back should give support". This is relevant to the Islamic leadership concept such as Shiddiq, Amanah, Tabligh, and Fathonah. This research impact can be applied at different educational levels which expect visionary and Islamic teaching, as well as leadership. Furthermore, the novelty is exploring the style of Ki Hadjar Dewantara's thinking about the leadership trilogy contained in educational book, which until now has been a reference for Islamic education.
\end{abstract}

Keywords Leadership, Tut Wuri Handayani, Islamic Education, Indonesia

\section{Introduction}

The leadership issue is related to the theories and trilogy concepts, which are ing ngarso sung tulodo, ing madyo mangun karso, tut wuri handayani. This is precisely directed, and in accordance with society character, where the culture is famous with the spirit of tolerance, humor, harmony, courtesy, noble, mutual cooperation, and humanists [1] [2].

This concept is apparently used by the government as a foothold and symbol in the education and teaching world. This is because it is considered to be very suitable and ideal for students, which should support and encourage education for achieving intelligence, goodness, future and leadership. The second indicator is derived from an expert that involved and concentrated expertise in the education field, named Ki Hadjar Dewantara. Therefore, various strategic concepts always refer to it [3][4].

According to Agus Cahyono's research titled "The Revitalization of the Noble Teachings of Ki Hadjar Dewantara", various aspects relating to education such as vision, mission, goals, curriculum and stage needs to be formulated based the people's willingness. Furthermore, Ki Hadjar Dewantara's ideas and thoughts have become a reference for the national education implementation.

In fact, ideas and thoughts from this man receive good acceptance from the first Indonesian president, Ir. Sukarno, and the principle that reads Ing ngarso sung tulodo, Ing madya mangun karso, Tut wuri handayani was derived from Hadjar's thoughts [5][6].

Meanwhile according to Supardi and Shodiq Kuncoro, Ki Hadjar Dewantara is widely known both at home and abroad due to the role played in national education which cannot be forgotten by the Indonesian people. The ideas 
have also succeeded in animating the national education system in particular, and the people's struggle. However, this does not eliminate the contribution and role of other figures that also paved way towards national education realization based on Pancasila [7].

Although there are many pros and cons because $\mathrm{Ki}$ Hadjar's birthday is made national education day, these provisions are appropriate because the conception in the education field such as Three Centers Theory, Among Systems, Tut Wuri Handayani, Pancadharma and science text books has aligned Ki Hadjar with world education figures, such as Frobel, Montessorie, Peztalozzi, John Dewey, Rabindranat Tagore, and others. Ki Hadjar inherited the services and soul of educators that did not prioritize groups, but the nation [7][8].

$\mathrm{Ki}$ Hadjar is always related to the establishment of Tamansiswa educational institutions and his struggle against the illegal school ordinance by the Dutch East Indies government. Kenji Tsuchiya's book titled Democracy and Leadership: The Rise of the Tamansiswa Movement in Indonesia stated that Ki Hadjar is a historical figure with priceless services in national education which will never be forgotten [9][10].

Furthermore, the basic problem of this research is to uncover the basis used to construct the theories contained in the trilogy, as well as examine it in from Islamic perspective. The main human goals in Islam are to become a leader (caliph) on earth. Therefore, the right knowledge or concept is needed to carry out these tasks [11].

\section{Materials and Methods}

A qualitative model is used with literature study, and data is obtained through written relics, both in form of books and scientific journals relevant to the issues discussed. An historical approach is also used, which is an instrument to reconstruct past events (history as past actuality) to become a story (history as written). Another approach is biographical, which is done by discussing and describing the thoughts or views of figures, religionists, politicians, or historians. Furthermore, the author also uses a normative and phenomenological approach [12], and data analysis techniques are processed according to its content. Comparative techniques were used by comparing two or three events based on the causes and reasons. This technique is used as a comparison effort to obtain comprehensive maximum results. Meanwhile, the steps are topic selection, sources collection, verification (historical criticism, sources validity), interpretation (analysis and synthesis), historiography or writing, and conclusions [13].

There are several relevant research obtained, such as Kenji Tsuchiya, (1987) titled Democracy and leadership: the rise of the Tamansiswa movement in Indonesia. Marwah and Syafe'i (2018), titled The Relevance of Educational Concept According to Ki Hadjar Dewantara with Islamic Education. Also, Marliani, L., \& Djadjuli, R.
D. (2019) titled Measuring Ki Hajar Dewantara's Leadership Trilogy in the Globalization Era. Benedictus Kusmanto and Sri Adi Widodo, (2016) titled Ki Hadjar Dewantara's Leadership Pattern. Rudolf Kempa, Marthen Ulorlo, Izaak Hendrik Wenno, 2017, titled Effectiveness Leadership of Principal. Siti Malikhah Towaf titled The National Heritage of Ki Hadjar Dewantara in Tamansiswa About Culture-Based Education and Learning, and Mujiono titled Methods in Learning Mathematics to Increase Problem Solving Skills and Constructing the Students Characteristics [14] [15] [2].

\section{Result and Discussion}

\subsection{Education and Leadership}

According to Supardi and Kuncoro, "Ing Ngarso Sung Tulodo, Ing Madyo Mangun Karso, Tut Wuri Handayani" implies that without exemplary leadership in front (ing ngarso), pro-actively following dynamics (ing madyo), and applying coaching or inherent supervision (tut wuri), understanding and implementation of future-oriented education, progress, and leadership will be impossible to achieve [7] [5].

Meanwhile, Kusmanto and Widodo explains that Ing ngarso means in front or upfront, Sung derived from the word Ingsun which means me, and Tulodo means role model. Therefore, Ing Ngarso Sung Tulodo meaning is leader should have a good attitude and behavior in all steps and actions in order to be a role model for subordinates. The word leader here can be interpreted as a teacher or educator that needs to set a good example [16] [17].

According to Ki Hadjar Dewantara, the motto and slogan "Ing Ngarso Sung Tulodo, Ing Madya Mangun Karso, Tut Wuri Andayani" use the word Andayani. Meanwhile, Mujiono stated that the motto "Ing Ngarso Sing Tulodo, Ing Madya Mangun Karso, Tut Wuri Handayani" use the words "sing" and "Handayani". Kusmanto used the word "mbangun" in "Madya mbangun karso". Meanwhile, Marwah and Syafe'i stated that the principle in Javanese read the letter "A" as "Ha", and the word Andayani was pronounced as Handayani. Therefore, this case use the term "Ing Ngarso Sung Tulodo, Ing Madya Mangun Karso, Tut Wuri Handayani" [14] [18].

Ing Madyo Mangun Karso. "Ing Madyo" means in the middle, "Mangun" means awakening or arousing and "Karso" is defined as will or a form of intention. Therefore, the word "Ing Madyo Mangun Karso" means a leader in the middle of his busy schedule should arouse subordinates' work spirit, and also provide innovations by creating a more conducive work environment for safety and comfort.

Ki Hadjar stated that the motto "Tut Wuri Handayani" means "to follow behind while influencing". This means not to pull children from the front, let them find their own 
way, and when they go wrong, the tutor (teacher) can correct them [19].

Based on the information above, Tut Wuri Handayani means the teacher follows from behind but closely supervises the students. The purpose of "follow behind" is to give them the freedom to find their own way. Meanwhile, teachers should provide corrections when necessary, for example when children face dangers they cannot avoid with their own thoughts or energy. According to Ki Hadjar Dewantara, this freedom is actually democracy in education and leadership [19].

Table 1. Educational Perspective of Leadership Trilogy

\begin{tabular}{|c|c|c|c|}
\hline No & $\begin{array}{c}\text { Leadership } \\
\text { Trilogy } \\
\end{array}$ & $\begin{array}{l}\text { Leadership } \\
\text { Perspective }\end{array}$ & $\begin{array}{l}\text { Educational } \\
\text { Perspective }\end{array}$ \\
\hline 1 & $\begin{array}{l}\text { Ing Ngarso } \\
\text { Sung Tulodo }\end{array}$ & $\begin{array}{l}\text { a leader should be } \\
\text { a role model for } \\
\text { subordinates. }\end{array}$ & $\begin{array}{c}\text { The teachers should } \\
\text { have good attitudes } \\
\text { and behaviors in their } \\
\text { actions in order to be a } \\
\text { role model for their } \\
\text { students. }\end{array}$ \\
\hline 2 & $\begin{array}{l}\text { Ing Madyo } \\
\text { Mangun } \\
\text { Karso }\end{array}$ & $\begin{array}{l}\text { a leader in the } \\
\text { middle of his } \\
\text { work should also } \\
\text { be able to arouse } \\
\text { the work spirit of } \\
\text { his subordinates }\end{array}$ & $\begin{array}{l}\text { a teacher should be } \\
\text { able to provide } \\
\text { innovations in the } \\
\text { classroom } \\
\text { environment in order } \\
\text { to create methods and } \\
\text { a learning atmosphere } \\
\text { that is conducive, safe } \\
\text { and comfortable for } \\
\text { learning. }\end{array}$ \\
\hline 3 & $\begin{array}{c}\text { Tut Wuri } \\
\text { Handayani }\end{array}$ & $\begin{array}{l}\text { A leader follows } \\
\text { behind while } \\
\text { giving a good and } \\
\text { inspiring } \\
\text { influence. }\end{array}$ & $\begin{array}{l}\text { Teachers should not } \\
\text { force students from } \\
\text { the front, let them find } \\
\text { their own way, and } \\
\text { when they go wrong, } \\
\text { the teacher may } \\
\text { correct them. }\end{array}$ \\
\hline
\end{tabular}

\subsection{Islamic Leadership}

Ki Hadjar Dewantara's trilogy which is summarized in "Ing Ngarso Sung Tulodho, Ing Madyo Mangun Karso, Tut Wuri Handayani" is actually an educational concept to build the character and ethics of indigenous, independent and liberate the people. Without exemplary leadership in the front (ing ngarso), pro-actively following the community dynamics (ing madyo), and applying guidance or inherent supervision (tut wuri), understanding and implementing education that liberates people's souls will be impossible to achieve. A leader that only governs cannot set good example, provide guidance and supervision, and thus cannot be a good role model, which is not in accordance with the ideals and desires of human development and Islamic values [20].

In 2017, the Ministry of Religious Affairs invited all members and staff, especially in the madrasa (Islamic school) environment to interpret "Tut Wuri Handayani" in Islamic concept. As an educator in the madrasa and family, a leader should also have the responsibility to translate the slogan triggered by Ki Hajar Dewantara in the form of Islamic religious sciences [21].

Ki Hadjar Dewantara states that Leaders and Educators have several meanings including "Tut wuri handayani" which means a teacher should be able to encourage and direct from behind. Secondly, "Ing Madya Mangun Karsa" which means they should create initiatives and ideas when with students. Thirdly, "Ingarsa sung tulada" means they should set an example with good actions when in front. Furthermore, teachers should also guide students with affection, for them to be free to develop their potentials. The concepts of Ki Hadjar dewantara and Islam are both guided based on compassion. This makes students develop themselves more freely because there is no pressure, and thus, the independent man can be achieved [14].

In Islamic thought, a good leader is like the prophet Mohammed that is blessed with four main foundations which are Sidiq, Amanah, Tablig and Fathonah. Sidiq means being honest in words and deeds, Amanah means trustworthy in maintaining responsibility, Tablig means conveying all kinds of goodness to the people and fathonah means being smart in managing society [17][22].

Sidiq/ Honest. Honesty is the main leadership and educator requirement, and community or students will certainly respect an honest individual. Leaders with this principle will be the foundation of their students' expectations because they are very aware that quality is determined by the followers' trust. Also, a leader that becomes a reference in front will be easily accepted in students' heart. However, a dishonest or treacherous leader will be hated. The honesty of a leader is judged by speech and attitude, which is a manifestation of commitment, and heart's reflection [23] [24].

Amanah is a mandatory virtue that should be owned, and by having a trustful nature, the leader will always maintain the community's trust, and they will surrender all kinds of affairs to be managed for mutual benefit [25].

Tablig / Communicative. Communication skills are the third quality a good leader should have. The subjects are not inanimate objects that can be moved at will, but are humans with various tendencies. Therefore, communication and diplomacy with students are the key to establishing good relationship. Furthermore, teachers are also required to open themselves to their students to get sympathy and love. This does not mean they should be open about all the obstacles being faced, but should be able to build and encourage trust for the students' future [26] [27].

Fathonah/ Smart. A leader or teacher should be more intelligent than the average people and students, which is accompanied by confidence. This will be important in solving different problems that occur in the community. Furthermore, an intelligent leader is not easily frustrated, and will appropriately and correctly solve problems [24] [28]. 
Table 2. The Trilogy Leadership and Islamic Leadership

\begin{tabular}{|c|c|c|c|}
\hline No & Islamic leadership & Leadership Trilogy & Meaning and relevance \\
\hline 1 & Siddiq & Ing Ngarso Sung Tulodo & $\begin{array}{c}\text { Leaders and teachers in front should be honest in } \\
\text { attitude and speech. }\end{array}$ \\
\hline 2 & Amanah & $\begin{array}{c}\text { Ing Ngarso Sung Tulodo Ing } \\
\text { Madyo Mangun Karso }\end{array}$ & $\begin{array}{c}\text { Leaders and teachers in front and middle should be } \\
\text { trustworthy and fair in decision making and provide } \\
\text { solutions to problems. }\end{array}$ \\
\hline 3 & Tabligh & $\begin{array}{c}\text { Ing Ngarso Sung Tulodo Ing } \\
\text { Madyo Mangun Karso }\end{array}$ & $\begin{array}{c}\text { Leaders and teachers in front and middle should be } \\
\text { able to convey ideas and be diplomatic. }\end{array}$ \\
\hline 4 & Fathonah & Tut Wuri Handayani & $\begin{array}{c}\text { Leaders and teachers should have an intelligent history } \\
\text { and background, and thus have the confidence to } \\
\text { encourage the community and students' progress. }\end{array}$ \\
\hline
\end{tabular}

\section{Conclusions}

Based on the results, there are three foundations used to strengthen leadership theory and education which are Ing Ngarso Sung Tulodo, which means a leader and educator should set a good example. Ing Madyo Mangun Karso, means those in the middle should take part and be cooperative. Tut Wuri Handayani, means those at the back should give support and encouragement. This conception is in harmony and relevant from Islamic perspective. This is because the three concepts are also in line with Islamic leadership theory and education such as Shiddiq (the leader and teacher in front should be honest in attitude and speech), Tabligh (those in the middle should be trustworthy and fair in their delivery), and Fathonah (the leaders and teachers should have an intelligent history and background to encourage the society and students' advancement).

\section{Acknowledgments}

The authors are grateful to the rector of Muhammdiyah University of Surakarta, Prof. Dr. Sofyan Anif and the chairman and staff of the LPPI UMS 2020 for supporting the publication of this article.

\section{REFERENCES}

[1] N. Nurhayati, C. Zahri Harun, and B. Bahrun, "The Principalrs Leadership Strategy in Improving Quality: A Study at Aron State Elementary School Pidie Aceh Indonesia," vol. 269, no. CoEMA, pp. 42-45, 2018.

[2] K. Kelch, "Becoming History. Taman Siswa and Its Influence on The Indonesian National Education," Master Thesis Res. Master Area Stud. Asia Middle East, vol. 2, no. 3, pp. 149-153, 2014.

[3] J. D. Pereira, "A Review of the Educational Leadership and Teacher Development Literature in Indonesia and Malaysia," HEAD Found., no. May, pp. 1-26, 2016.

[4] Muthoifin, "Ki Hadjar Dewantara Educational Thought Perspective of Islamic Education," in Prosiding ICTEE FKIP UNS, 2016, vol. 1, pp. 773-779.
[5] W. Asrowi, "Effectiveness of Social Science Learning Based on Noble Values of Ki Hajar Dewantara's Teaching to Strengthen the Students' Character How to Cite," IJAL Int. J. Act. Learn., vol. 2, no. 1, pp. 1-14, 2017.

[6] M. Claramita, "Revealing 'Tut Wuri Handayani' - A Student-Centred Learning Approach- by Ki Hajar Dewantara from The Early 20th Century: A Literature Review," J. Pendidik. Kedokt. Indones. Indones. J. Med. Educ., vol. 5, no. 1, pp. 1-14, 2016.

[7] S. A. Supardi, Kuntoro, S. Irine, and A. Dwiningrum, "Ki Hadjar Dewantara and Rabindranath Tagore 'S Thought," IJSS, vol. 14, no. 1, pp. 48-62, 2018.

[8] A. Sukasni and H. Efendy, "The Problematic of Education System in Indonesia and Reform Agenda," Int. J. Educ., vol. 9, no. 3, p. 183, 2017.

[9] M. Cholil, "Complexities In Dealing With Gender Inequality: Muslim Women and Mosque-Based Social Services in East Java Indonesia," J. Indones. Islam, vol. 11, no. 2, p. 459, 2017.

[10] K. Tsuchiya, Democracy and leadership: the rise of the taman siswa movement in Indonesia. Kyoto: Honolulu: University of Hawaii Press, 1987.

[11] H. Nashir, M. Jinan, and B. Setiaji, "Muhammadiyah: the Political Behavior of Modernist Muslim Elite in Indonesia," Humanit. Soc. Sci. Rev., vol. 7, no. 4, pp. 837-844, 2019.

[12] C. Williams, "Research Methods," J. Bus. Econ. Res., vol. 5, no. 3, pp. 65-72, 2007.

[13] Muthoifin and Nuha, "the Optimization of Local Autonomy Politic for Nation Progress and Synergetic on Islamic Perspective," in The 4th University Research Coloquium 2016, 2016, pp. 72-79.

[14] Mujiono, "Among Method in Learning Mathematics to Increase Skill of Problem Solving and Construct the Character of Students," in The International Conference on Mathematical Analysis, Its Applications and Learning 2018, 2018, pp. 34-43.

[15] R. Kempa, M. Ulorlo, and I. Hendrik Wenno, "Effectiveness Leadership of Principal," Int. J. Eval. Res. Educ., vol. 6, no. 4, p. 306, 2017.

[16] A. F. Noor and S. Suyanto, "The Analysis of Character Strengthening Strategy based on Teaching of Ki Hajar Dewantara in Industry 4.0," Adv. Soc. Sci. Educ. Humanit. Res., vol. 335, no. ICESSHum, pp. 1002-1009, 2019. 
[17] Y. Hartono, S. Haryanto, and Asrowi, "Character Education in the Perspective of Humanistic Theory: A Case Study in Indonesia," Educ. Int. J. Educ. Stud., vol. 10, no. 2, pp. 95108,2018

[18] B. Kusmanto and S. A. Widodo, "Pola Kepemimpinan Ki Hadjar Dewantara," Manag. Pendidik., vol. 11, no. 2, pp. 18-29, 2016.

[19] L. Nugroho, "The Implementation of an Trilogi Educational Leadership To Ki Hadjar Dewantara in Elementary School (SD) Taman Muda Ibu Pawiyatan Taman Siswa of Yogyakarta," J. Kebijak. Pendidik., vol. 6, pp. 205-214, 2017

[20] N. J. G. Kaptein, “Two Unknown Letters from the Kartini Family to M.J. de GoejeDeux lettres inédites de la famille Kartini à M.J. de Goeje," Archipel, no. 93, pp. 109-117, 2017.

[21] Suprapto, "Sasak muslims and interreligious harmony: Ethnographic study of the perang topat festival in Lombok Indonesia," J. Indones. Islam, vol. 11, no. 1, pp. 77-98, 2017.

[22] A. H. Usman, "Humanism In Islamic Education: Humanism : Historical Perspectives The term " humanism " has a complex history and meaning. " Humanism " as The humanist movement evolved and became the forerunner of the In the early blooming of humanism in Europe , human,"
IJAPS, vol. 13, no. 1, pp. 95-113, 2017.

[23] H. P. Daulay and Tobroni, "Islamic Education In Indonesia: A Historical Analysis Of Development And Dynamics," Br. J. Educ., vol. 5, no. 13, pp. 109-126, 2017.

[24] S. shobron Muthoifin and S. A. Rahman, "Humanist islam in indonesia ahmad syafii maarif perspective," Humanit. Soc. Sci. Rev., vol. 7, no. 6, pp. 780-786, 2019.

[25] Muthoifin, "Shariah Hotel and Mission Religion in Surakarta Indonesia," Humanit. Soc. Sci. Rev., vol. 7, no. 4, pp. 973-979, 2019.

[26] Usep Abdul Matin, "The Roots of Violence in Westren Social Theories: In Search of Solution for Islam and Modernity," Insa. J. Islam Humanit., vol. 3, no. 2, pp. 139$150,2019$.

[27] Biyanto, "The Views of Young Muhammadiyah Intellectuals Biyanto," J. Indones. Islam, vol. 03, no. 02, pp. 314-340, 2009.

[28] A. S. Maarif, "Islam, Humanity, and Indonesian Identity reflections on history," in Leiden University Press, 2018, pp. $1-289$.

[29] A. S. Sudarno Shobron, Mutohharun Jinan, MA Fattah Santoso, Muthoifin, "Contribution Boarding Schools For Social Changes In Central," Int. J. Psychosoc. Rehabil., vol. 24, no. 06, pp. 7851-7859, 2020. 